\title{
From hazard reduction to integrated risk management: toward adaptive flood prevention in Europe
}

\author{
F. Vinet \\ Department of geography, University of Montpellier III, France
}

\begin{abstract}
Flood risk has long been seen only as a hydrological phenomenon. Flood risk management has therefore been directed almost exclusively toward curative methods. Dykes and dams have attempted to contain the floods while crisis management and insurance have compensated for loss. However, the acknowledgement of human responsibility in natural disasters has widened the epistemological field of natural-hazards knowledge integrating the concept of vulnerability. Recent and disastrous floods all over the world have highlighted the relative failure of the existing risk-management system. Over the past fifteen years, the increasing cost of damage has caused a reaction of the authorities, who have expressed through various laws and incentive measures their wish to develop integrated risk management. The integrated approach uses not only curative methods but also land-use planning, reduction of vulnerability and the development of public awareness by implementing local emergency plans. Through some examples in France, this presentation aims to suggest new ways of assessing risk-management measures. The French territory, located between northern and southern Europe, is concerned by all kinds of floods: slow-rise floods in its northern part and flash floods in mountainous and Mediterranean regions. For many years, the top-down institutional approach has led to the implementation of measures ill-adapted to Mediterranean regions. Thus, this presentation shows how some measures, efficient for slow floods, are inefficient for Mediterranean torrential floods. While the new European Directive on Flood Risk is willing to reinforce flood prevention in Europe, it is important to take into account the specific characteristics of each basin and each hydrological context before implementing flood-reduction measures such as upstream control, vulnerability reduction or flood warning. Stakeholders and institutions might implement an adaptive and territorial approach in flood prevention so as not to repeat the serious mistakes that we have seen for many years.
\end{abstract}

Keywords: natural hazards, floods, vulnerability, mitigation, flood risk management, European directive, Mediterranean basin. 


\section{Introduction}

After recent floods, many reports noted the relative failure of traditional flood prevention measures such as flood warnings or flood-defence systems. After an overview of those failures, we examine the necessary changes in flood prevention. One of the major changes is to consider spatial discrepancies between basins and different kinds of floods. Indeed, in France slow-rise floods and flash floods shall not be addressed in the same ways. Thanks to the example of the upstream control strategy, we will see how this method might be implemented with cautiousness in watersheds stricken by flash floods.

\section{The failure of traditional approaches to flood prevention}

\subsection{The traditional methods of flood prevention}

Following Pelling [1], we can distinguish three phases in epistemological interpretation from the natural risk. The "traditional" vision or "hazard paradigm", as it is called by Parker [2], prevails at least until the end of the 1970s. Firstly, the specialized authors, in particular the Chicago School of geographers, see the risk as a potentiality of the occurrence of a destructive natural phenomenon the origins of which are external to human society. The dichotomy is clear and the causal relation is simple: the natural phenomenon strikes a community or a territory that suffers damage. It seems difficult then in people's minds to find in disasters other explanations than paroxysmal demonstrations of a natural phenomenon (earthquakes, storms...). Thus, the first approach, which still prevails in some minds, supposes that society and territories stricken by a natural agent must be defended and have to set up protection. The extreme natural phenomena are external disturbing elements against which it is necessary to fight. In the $19^{\text {th }}$ and $20^{\text {th }}$ centuries, dominated by wars, building up levees was the "natural" answer to this vision. In the USA, the Army Corps of Engineers (USACE) is in charge of building and maintaining levees. For a long time, flood prevention had been limited to either flood defence systems or warning and crisis management.

The second phase comes with the recognition of the human role in the process by which disasters are produced. By the beginning of the 1980s, the vision had changed. Hewitt [3] introduced society as part of the system of production of risk. Thus, risk is not merely the possibility of a disturbance by an external natural agent: the society itself generates risk through vulnerability. Therefore, to prevent risk, one can mitigate human vulnerability.

The third phase, as from the 1990s, develops an integrated vision of the natural risks and their management associating hazard and anthropogenic vulnerability, the complexity of the causal relations and a recontextualisation of the risks within the entire social system. 


\subsection{Recent disasters show the failure of traditional measures}

Many disasters (floods in Europe in 2002 and Hurricane Katrina in the USA in 2005) due to flooding have highlighted the failure of existing prevention measures such as dikes, land-use planning and flood-warning systems.

The problem of the rupture of levees is more complex and difficult to manage. The reason why levees appear to be a problem is that they now are getting older and suffer from a lack of maintenance. The authorities then in charge of dike maintenance couldn't afford the needed repairs. They had neither the technical competence nor the financial resources necessary to accomplish this task. It was urgent to empower stakeholders and dike owners by giving them all the juridical, technical and financial means to maintain the dike systems. The second reason is the uncontrolled expansion of urbanization behind the dikes. In France, as in many countries, land-use planning failed to control the establishment of houses and activities in flood-prone zone [4]. At the same time, dikes are built for a certain level of risk recently exceeded in various disastrous floods (e.g. Katrina). The last problem with dikes was that dike failure was seldom included in warning plans, primarily because they often are believed unsubmersible by riverside dwellers. Moreover, it is difficult to simulate the return period of a dike failure.

Dike failure is only one example of traditional ways of prevention. The same observations have been made for other issues such as flood warning or land-use planning.

\subsection{How to overstep the "occidental paradox"?}

Despite those problems, the paradox is that our so-called "developed countries" have never been so safe. The CRED database shows that the number of fatalities due to natural disasters has regularly decreased since the beginning of the $20^{\text {th }}$ century. Meanwhile, the citizens' increasing demand for safety weighs heavily on the shoulders of both politicians and decision makers. Considering natural risks as problems with both natural and social origins [2, 3], a large field of management is possible. Beyond the traditional structural methods, it becomes possible to decrease the consequences of floods not only by controlling land use but also by relocating or reducing the vulnerability of dwellings and industries in flood-prone zones. Much progress had be obtained by investments of public founds. Nonetheless, the relative failure of traditional means of prevention is also due to ill-adapted methods. In the 19th century, state officials had the authority and controlled the management of floods. Now, however, a point of discussion is to overstep the institutional approach to implementing local solutions. The state cannot support the whole weight of flood prevention. The institutional approach, i.e., the top-down management of risk by state institutions, has reached its limits [5]. New progress might be obtained addressing an integrated and territorial approach to flood prevention. 


\section{For an integrated and territorial approach to flood prevention}

\subsection{An integrated approach to flood prevention}

An integrated approach to flood prevention is recommended by many authors and guidelines, but it is sometimes difficult to implement such an approach on a local scale. The flood management first has to be technically integrated. It means that all measures are to be considered before implementing any management plan. The French Ministry of Ecology decided to launch a call for flood management plans (FMP called PAPI in French). The circular of October $1^{\text {st }}$, 2002, that has fixed the characteristics of those plans, was adopted three weeks after the floods of the Gard of September $9^{\text {th }}, 2002$. The projects may fulfil three conditions:

- A high level of risk regarding the basin in question

- The validity of the plan taking into consideration the above criterion

- The credibility of the river-basin authorities

- An integrated management of floods at the catchment level

Spatially, the call for project recommends reinforcing upstream-downstream solidarity by promoting the « Dynamic Flood Slowing Down Strategy » i.e. the storage of water in the basin upstream in order to slow down and to decrease the peak discharge.

The technical integration of the projects supposes the association of traditional structural methods and measures (dams, retaining tanks), non structural measures such as information disseminated to flood prone populations, the reduction of vulnerability, and land-use control. Here are the five types of plans:

- Issue 1: Public information and awareness

- Issue 2: Forecast and warning, crisis management

- Issue 3: Vulnerability mitigation, and relocation

- Issue 4: Upstream flood control

- Issue 5: Collective protection (dikes and floodwalls)

The French state does condition grants for flood prevention upon the existence of a strong basin authority covering the whole catchment.

\subsection{A territorial approach to flood management}

At the same time, a territorial approach to flood management implies several principles. Flood-risk management must address the particularities (natural and social) of each territory. The flood risk has to be managed considering the entire catchment. It is to be handled in accordance with the principles of sustainable development. It means that a mitigating measure tested in a catchment may not be successful in all other river-basin districts. It depends on the return period considered, the density of human settlements to protect, the acceptability of the measures, their costs, etc. 
Developing the example of upstream control, we may demonstrate that upstream control, recommended by the call for projects for FMP by the French Ministry of Ecology is not really feasible and efficient in small Mediterranean basins.

\section{The need to address territorial particularities in flood-risk management: the case of upstream control in Mediterranean basins}

\subsection{Flash floods vs. slow floods: the characteristics of flash floods in Mediterranean basins}

As in Europe as a whole, France has an oceanic climate in its north and a Mediterranean climate in the south. Thus, the northern part of the country is affected by slow-rise floods whereas southern and mountainous regions suffer from flash floods. Despite little spatial extension, Mediterranean flash floods are very damaging [6]. National authorities and international organisations sometimes neglect this kind of flood because it concerns small catchments. Table 1 gives the amount of damage to properties for recent major floods in France. Flash floods that occurred under Mediterranean climate are highlighted. Thus, according to insurance companies, Mediterranean flash floods trigger $66 \%$ of the damage due to flooding in France. If we include damage on public infrastructures and industries, two major torrential floods in 1999 and 2002 caused 58 fatalities and 2 billion euros of damage.

Before assessing the efficiency of prevention measures, let us recall the specific hydrological and geomorphological characteristics of Mediterranean regions.

Peak discharges are among the highest in the extra-tropical world. They have been studied by Gaume et al. [7]. In small watersheds (fewer than $20 \mathrm{~km}^{2}$ ), the peak discharges exceeded $10 \mathrm{~m}^{3} / \mathrm{s} / \mathrm{km}^{2}$, sometimes $20 \mathrm{~m}^{3} / \mathrm{s} / \mathrm{km}^{2}$ in the core of a flooded zone reported as peak discharge. Thus, damage is due not only to large rivers but also to strong runoff coming down from little watersheds. It explains the heavy damage to roads and networks. In the department of the Aude, 14 bridges and 29 water-treatment centres were destroyed, mainly in narrow upper valleys. Between 1996 and 2006, the estimated human toll of flooding in southern France was around 150 fatalities.

The topographical and geomorphological characteristics explain the strength of flash floods. The river basins are rather small. Except for big rivers such as the Rhône in France or the Po in Italy that flow down from extra-Mediterranean regions, the Mediterranean riversides are bordered by small watersheds (from 500 to $5,000 \mathrm{~km}^{2}$ ) due to the short distance between mountains and sea. The runoff begins on hills of altitudes from 500 to 2,500 meters. The high valleys are rather steep. The strong declivity contributes to generating flash floods with stream velocities sometimes reaching seven meters per second. Further downhill, the valleys become larger and the flood-prone zone is 500 to $1,000 \mathrm{~m}$ wide. These are "piedmonts" where the density of population is higher (50 to 100 
habitants per $\mathrm{km}^{2}$ ) and grapes are the main crop. Proceeding seaward, the rivers leave the piedmonts and flow into low plains. In general, the water flows between dikes. The speed of the water is slower (less than $1 \mathrm{~m} . \mathrm{s}^{-1}$ ) and the peak discharge usually comes several hours, sometimes one day, after having affected the high part of the watershed. Huge damage is sustained when dikes and levees fail. In this context, we can wonder whether upstream control is a good solution to reduce flood risk.

Table 1: The cost of floods in France according to climatic domains (source: Caisse Centrale de Reassurance/CCR and insurance companies) in millions of euros.

\begin{tabular}{|c|c|c|c|}
\hline Year & $\begin{array}{l}\text { Month and affected places (towns or } \\
\text { departments) }\end{array}$ & $\begin{array}{l}\text { Oceanic } \\
\text { floods } \\
\text { (slow-rise } \\
\text { floods) }\end{array}$ & $\begin{array}{c}\text { Mediterra } \\
\text { nean } \\
\text { Floods }\end{array}$ \\
\hline 1988 & October (Nîmes - Gard) & & 290 \\
\hline 1990 & February (all northern France) & 183 & \\
\hline 1992 & September (Vaison-la-Romaine) & & 244 \\
\hline 1993 & $\begin{array}{l}\text { September/October (downstream Rhone river } \\
\text { basin) }\end{array}$ & & 305 \\
\hline $\begin{array}{c}1993- \\
1994\end{array}$ & December/January & 259 & \\
\hline 1994 & November (Nice) & & 122 \\
\hline 1995 & January/February (Britain and northern France) & 365 & \\
\hline 1996 & December (South-West) & 76 & \\
\hline 1997 & June (Normandy) & 28 & \\
\hline 1998 & October (Meurthe-et-Moselle) & 11 & \\
\hline 1999 & November (Aude) & & 222 \\
\hline 1999 & $\begin{array}{l}\text { Floods linked to Lothar and Martin Storms } \\
\text { (Northern France) }\end{array}$ & 234 & \\
\hline 2000 & September (Marseille) & & 51 \\
\hline 2000 & December (Britain) & 73 & \\
\hline 2001 & January (Britain, Normandy) & 40 & \\
\hline 2001 & April (Somme) & 70 & \\
\hline 2002 & September (Gard department) & & 640 \\
\hline 2003 & December (downstream Rhone river basin) & & 744 \\
\hline 2005 & July (North/Pas-de-Calais) & 45 & \\
\hline \multirow[t]{2}{*}{2005} & September (Gard/Hérault) & & 100 \\
\hline & Total & 1384 & 2718 \\
\hline
\end{tabular}

\subsection{Is upstream control efficient and feasible in Mediterranean catchments?}

Upstream control is a method to store waters in upper sub-basins in order to slow down and decrease the peak discharge in flood-prone zone areas downstream. 
Everybody is familiar with the bypassing channels or flood storage areas that provide efficient decrease in flow on many European rivers [8]. This method is encouraged by many guidelines coming from the European Union or the French Ministry of Ecology [9]. The circular of October 1st, 2002, insists on "the regulation of the flow to the upstream (which) is technically often recommended". Thus, all flood-management plans are to include upstream control in order to comply with the Ministry's wishes. Nevertheless, the feasibility and efficiency of upstream control is not obvious.

Waters can be stored either in floodplain storage areas or in storage basins.

For the first solutions, Mediterranean catchments do not offer many possibilities for waters to expand because the valleys are steep. Downstream, when the valleys get wider, the floodplains are often occupied by dwellings or the tourism industry. The volume of waters that could be stored is disproportionate compared with rainfall depth, as we will see later. Nevertheless, floodplain storage areas are recommended to stop urbanization and make the people aware that rivers need a "space of freedom". They are also recommended for collecting floating debris (such as trees or cars) in order to prevent debris jams behind bridges.

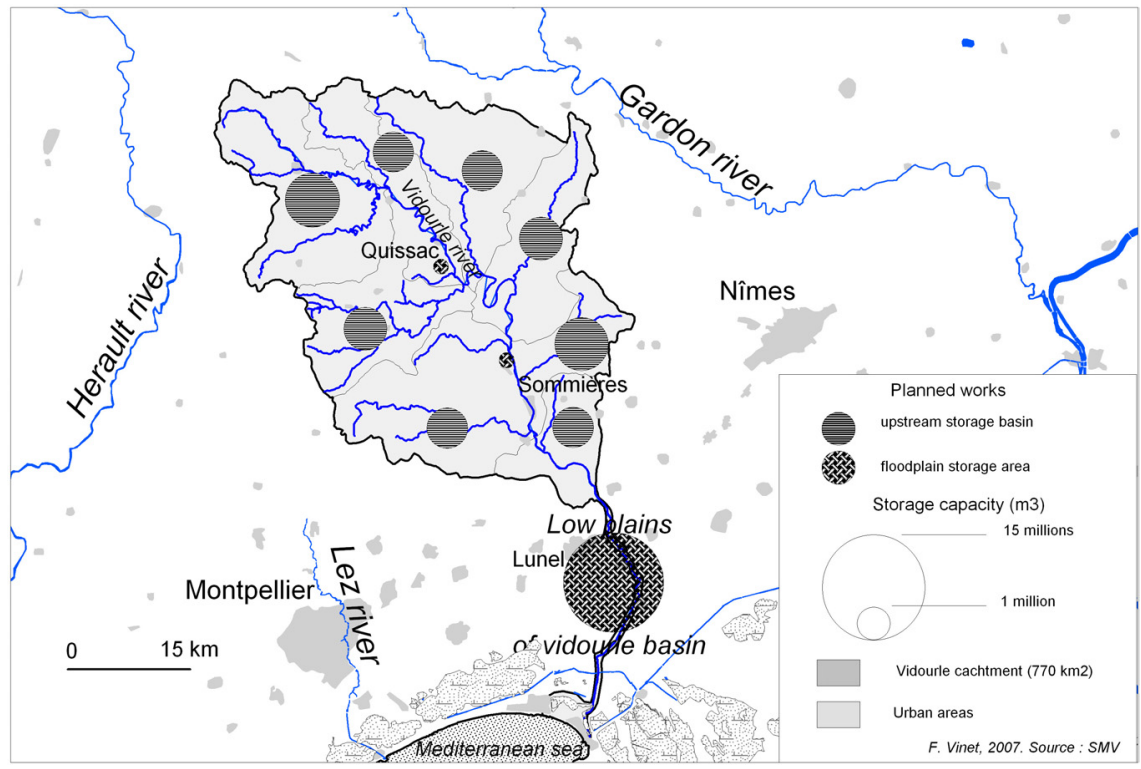

Figure 1: $\quad$ Planned flood storage basins in the Vidourle catchments.

The hope for an effective reduction of peak discharge has relied on the settlement of many flood-storage basins in the upstream part of a basin. The flows and volumes of water to be stored are to be compared with rainfall depth and runoff. Let us take the example of Vidourle basin in southern France. This $770 \mathrm{~km}^{2}$ wide basin ran off a $2400 \mathrm{~m}^{3} \cdot \mathrm{s}^{-1}$ peak discharge during the floods of September 9, 2002. This discharge is quite similar to the 1910 historic flooding 
of the Seine River in Paris (watershed area: 44,500 $\mathrm{km}^{2}$ ). According to hydrological reconstitutions, 220 million $\mathrm{m}^{3}$ flowed out of the Vidourle basin during this event. Thus, after the floods, the flood management project had planned in a preliminary draft 56 suitable sites for small storage basins $(0.2$ to 0.5 million $\left.\mathrm{m}^{3}\right)$ and 11 sites for basins with large capacity $\left(1.5\right.$ million $\left.\mathrm{m}^{3}\right)$; the whole being 41 million $\mathrm{m}^{3}$ including 15 million $\mathrm{m}^{3}$ in natural retention areas in low valleys (figure 1). If the program is applied, the volume of water intercepted by the storage basins reaches $10 \%$ and $20 \%$ according to the sub-basins and $28 \%$ for the entire basin, in case of fifty-year return-period rainfalls. At the present time, the Vidourle River Basin Authority is launching the five first storage basins. Their cost is estimated at 11 million euros for a 2.5 million-cubic-meter storage capacity, i.e. 4.5 euros per cubic meter. This volume just exceeds $1 \%$ of 2002 floods total run off.

Moreover, the building of such a water retention program is likely to face many constraints. Table 2 describes these constraints. The first one is financial. The cost of maintenance of the works ought to be $3 \%$ of investment cost per year. Will the basin authority be able to pay without the huge and constant help of the state? Will other programs of flood prevention such as vulnerability reduction or public information not suffer from lack of subsidies?

Table 2: Advantages and disadvantages of upstream control by storage basins.

\begin{tabular}{|c|c|c|}
\hline Flood-retention basins & Expected costs & Expected benefits \\
\hline \multirow{4}{*}{ Building } & Cost of works & \multirow{3}{*}{$\begin{array}{l}\text { Reducing peak } \\
\text { discharge } \\
\text { Downstream }\end{array}$} \\
\hline & $\begin{array}{l}\text { Preliminary studies for } \\
\text { the choice of place }\end{array}$ & \\
\hline & Land acquisitions & \\
\hline & Accessibility & \multirow{4}{*}{$\begin{array}{c}\text { Increasing warning } \\
\text { lead time }\end{array}$} \\
\hline \multirow{3}{*}{ Maintenance } & Aesthetic disagreement & \\
\hline & Cost of maintenance & \\
\hline & $\begin{array}{l}\text { Cost of restoration if } \\
\text { floods }\end{array}$ & \\
\hline \multirow{2}{*}{$\begin{array}{c}\text { Possible } \\
\text { consequences }\end{array}$} & Failure risk & \multirow{6}{*}{$\begin{array}{l}\text { Reducing debris } \\
\text { jams } \\
= \\
\text { Conversion into } \\
\text { economical value }\end{array}$} \\
\hline & $\begin{array}{c}\text { Inefficiency in case of } \\
\text { huge flood (two peak } \\
\text { discharges) }\end{array}$ & \\
\hline \multirow{2}{*}{$\begin{array}{l}\text { * hydrological } \\
\text { * biological and } \\
\text { geomorphological }\end{array}$} & $\begin{array}{l}\text { Change in sediment } \\
\text { flows, siltation }\end{array}$ & \\
\hline & Environmental changes & \\
\hline \multirow[b]{2}{*}{ * social } & $\begin{array}{c}\text { Reduction of flood } \\
\text { awareness }\end{array}$ & \\
\hline & $\begin{array}{l}\text { New settlements in } \\
\text { flood-prone zone } \\
\text { downstream }\end{array}$ & \\
\hline
\end{tabular}


Occasionally, upstream communities sometimes refuse to allow such works on their territory. They do not wish to pay for downstream communities that have not managed to control urbanization.

Of course, flood-management plans are prudently drawn up. The entire program is not likely to be implemented.

It is necessary to distinguish the conditions of the efficiency of upstream control. Local tanks are efficient when intended to regulate a specific problem like decreasing flow while crossing urban areas. In catchments prone to severe flash floods, however, massive programmes of storage basins are not really effective and are rather expensive, while their consequences on the environment are likely to be substantial. Engineers, authorities and companies in charge of flood mitigation should expand their competencies and test others ways of prevention.

\subsection{The new European directive and the territorial discrepancies in Europe}

The European Directive 2007/60/EC was drawn up in October 2007 to implement a policy of flood-risk assessment and prevention in the EC. Member States are invited to assess and map flood risk in order to implement flood-risk management plans. The flood-management plans implemented by the French Minister of the Environment attempts to provide a first response [10]. They ought to be the prelude to the plans as recommended by the European directive.

This directive recognizes that "throughout the Community different types of floods occur, such as river floods, flash floods, urban floods and floods from the sea in coastal areas. The damage caused by flood events may also vary across the countries and regions of the Community. Hence, objectives regarding the management of flood risks should be determined by the Member States themselves and should be based on local and regional circumstances". This statement is particularly important in order to address flash floods and slow floods differently.

Moreover, this directive focuses on major events. Article 6 states that "flood hazard maps shall cover... floods with a low probability, or extreme event scenarios; and floods with a medium probability (likely return period $>100$ years) and floods with high probability, where appropriate." The focusing on major events to draw up and to implement flood management plans will have two consequences. It first neglects the prevention of current floods. This kind of flood (with a return period of between 10 and 50 years) is very disturbing for populations and expensive for insurers. In many cases, the cost-benefit ratio of mitigation measures is interesting. Secondly, it can focus investments on huge protections, preparing for forthcoming disasters by weakening the public awareness in flood-prone and in supposed protected zones.

\section{Conclusion}

Future progress in flood prevention will not be proportional to the foreseen levels of investment, but rather to the capacity of those involved to coordinate 
with one another and to implement solutions adapted to local particularities. French experience in flood-management plans shows that some solutions are efficient for slow floods but difficult to implement in small Mediterranean watersheds. One hopes that the new European Directive will avoid promoting general and "fashionable" measures of flood prevention. It is an opportunity to consider the differences in characteristics of all the river basins of Europe.

\section{References}

[1] Pelling, M., The vulnerability of cities. Natural disaster and social resilience. Earthscan Publications Ltd., 2003.

[2] Parker, D.J. (ed). Floods. Routledge: London, 2000.

[3] Hewitt, K., (ed). Interpretation of calamity from the viewpoint of Human Ecology, Boston: Allen and Unwin, 1983.

[4] Pottier, N., Penning-Rowsell, E., Tunstall, S. \& Hubert, G., Land use and flood protection: contrasting approaches and outcomes in France and in England and Wales. Applied Geography, 25, pp. 1-27, 2005.

[5] Hutter, G., Strategies for flood risk management - A process perspective, Flood risk management. Hazards, vulnerability and mitigation measures, eds J. Schanze, E. Zeman \& J. Marsalek, Springer-Verlag: Berlin and New York, NATO Science series, IV, Environmental sciences, vol. 67, pp. 229 246, 2006.

[6] Belmonte, A. C. \& Beltran, F. S., Flood events in Mediterranean ephemeral streams (ramblas) in Valencia region, Spain. Catena. 45, pp. 229-249, 2001.

[7] Gaume, E., Livet, M., Desbordes, M. \& Villeneuve, J. P., Hydrological analysis of the river Aude, France, flash flood on 12 and 13 November 1999. Journal of Hydrology, 286, pp. 135-154, 2004.

[8] Szlavik, L., Emergency flood reservoirs in the Tisza Basin. Flood issues in contemporary water management, ed. Marsalek et al., Kluwer Academic Publishers: Dordrecht, Boston and London, NATO Sciences Series, 2000.

[9] MEDD/Cemagref, Le ralentissement dynamique pour la prévention des inondations, 2004.

[10] Vinet, F., Flood risk management in French Mediterranean basins. River Basin Management IV, ed C.A. Brebbia. \& Katsifarakis, WIT Press, pp. 261-270, 2007. 